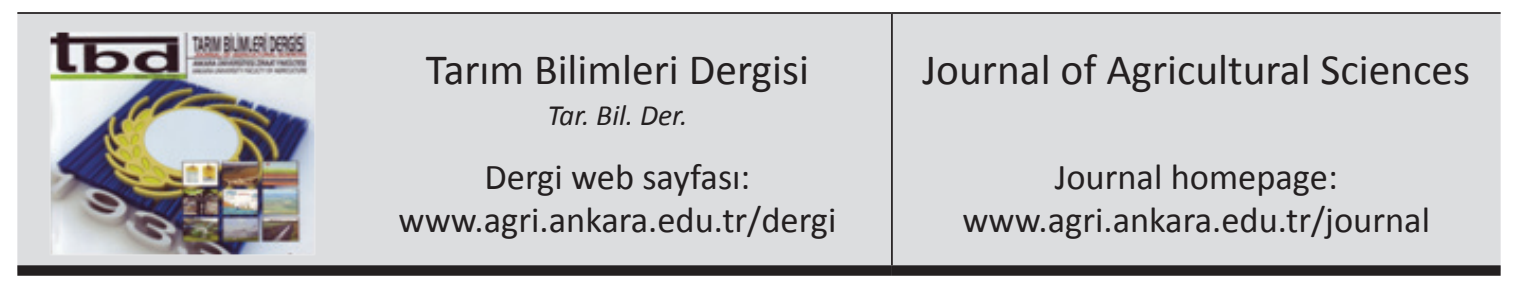

\title{
The Effect of Different Harvest Stages on Chemical Composition and Antioxidant Capacity of Essential Oil from Artemisia annua L.
}

\author{
Belgin COŞGE ŞENKAL ${ }^{\mathrm{a}}$, Mustafa KIRALAN ${ }^{\mathrm{b}}$, Cennet YAMAN ${ }^{\mathrm{a}}$ \\ ${ }^{a}$ Bozok University, Faculty of Agriculture and Natural Sciences, Department of Field Crops, Yozgat, TURKEY \\ ${ }^{b}$ Abant İzet Baysal University, Faculty of Engineering and Architecture, Department of Food Engineering, Bolu, TURKEY
}

\section{ARTICLE INFO}

Research Article

DOI: $10.1501 /$ Tarimbil 0000001308

Corresponding Author: Belgin COŞGE ŞENKAL, E-mail: belgin.senkal@bozok.edu.tr, Tel: +90 (354) 2421028 / 44 62 Received: 26 January 2014, Received in Revised Form: 14 May 2014, Accepted: 21 May 2014

\begin{abstract}
Chemical composition of the essential oils obtained by hydro-distillation from Artemisia annua L. (Asteraceae) harvested before flowering $(\mathrm{BF}), 50 \%$ of flowering $(50 \% \mathrm{~F})$, full flowering $(\mathrm{FF})$, and after flowering $(\mathrm{AF})$ stages were determined using $\mathrm{GC}$ and $\mathrm{GC} / \mathrm{MS}$ analysis. The essential oil contents were $0.8 \%, 0.96 \%, 1.22 \%$ and $1.38 \%$ in $\mathrm{BF}, 50 \% \mathrm{~F}, \mathrm{FF}$ and $\mathrm{AF}$, respectively. In total, 20 compounds were identified, with artemisia ketone (28.30\%-37.15\%), camphor (18.00\%$23.30 \%$ ), and 1,8-cineole $(9.00 \%-10.39 \%)$ as main components. The highest amounts of the three main components were recorded in the essential oils of the plants harvested in the FF stage. Also, the free radicals scavenging activity of the essential oils, tested by using DPPH method, were found to be in order of $\mathrm{FF}>50 \% \mathrm{~F}>\mathrm{AF}>\mathrm{BF}$.

Keywords: Artemisia annua L.; Essential oil; Artemisia ketone; Antioxidant; DPPH
\end{abstract}

\section{Artemisia annua L.'dan Elde Edilen Uçucu Yağın Kimyasal Kompozisyonu ve Antioksidan Kapasitesi Üzerine Farklı Hasat Dönemlerinin Etkisi}

\section{ESER BILLGISI}

Araştırma Makalesi

Sorumlu Yazar: Belgin COŞGE ŞENKAL, E-posta: belgin.senkal@bozok.edu.tr, Tel: +90 (354) 2421028 / 4462

Geliş Tarihi: 26 Ocak 2014, Düzeltmelerin Gelişi: 14 Mayıs 2014, Kabul:21 Mayıs 2014

\section{ÖZET}

Çiçeklenme öncesi (ÇÖ), \% 50 çiçeklenme (\% 50 Ç), tam çiçeklenme (TÇ) ve çiçeklenme sonrası (ÇS) dönemlerinde hasat edilen Artemisia annua L. (Asteraceae)'dan su distilasyonu yöntemiyle elde edilen uçucu yağların kimyasal kompozisyonu GC ve GC/MS kullanılarak belirlenmiştir. Uçucu yağ içerikleri ÇÖ, \% 50 Ç, TÇ ve ÇS dönemlerinde sırasıyla \% $0.8, \%$ 0.96, \% 1.22 ve \% 1.38 bulunmuştur. Toplamda 20 bileşenin tespiti yapılmış olup, artemisia ketone ( $\% 28.30-\% 37.15)$, camphor (\% 18.00-\% 23.30) ve 1,8-cineole (\% 9.00-\% 10.39) ana bileşenler olarak belirlenmiştir. Üç ana bileşene ait en yüksek değerlere tam çiçeklenme döneminde hasat edilen bitkilerin uçucu yağlarında kaydedilmiştir. Ayrıca, DPPH yöntemiyle test edilen uçucu yağların serbest radikal yakalama aktivitesi $\mathrm{TÇ}>\% 50$ Ç $>C ̧ S>C ̧ O ̈$ sırasında bulunmuştur.

Anahtar Kelimeler: Artemisia annua L.; Uçucu yağ; Artemisia ketone; Antioksidan; DPPH 


\section{Introduction}

The genus Artemisia contains more than 400 species, and distributed mainly in the Northern Hemisphere, especially in Asia, Europe and North America (Pellicer et al 2006; Nibret \& Wink 2010). This genus is represented by 22 species in Turkey (Tubives 2013). Many species of the genus Artemisia are used as spices, for alcoholic drinks and also in the folk and traditional medicine (Baser \& Buchbauer 2010).

Artemisia аппиа L. (Asteraceae), commonly named sweet wormwood, sweet annie, annual wormwood etc., is a fragrant annual herb ( $\mathrm{C}^{\prime}$ avar et al 2012). A. аnnua is also known locally as "Yavşan otu", "Kabe süpürgesi", "Kabe kekiği" and "Peygamber süpürgesi" in Turkey (Tubives, 2013). It is the only commercial source of artemisinin (Ferreira et al 2013), a potent antimalarial drug (Woerdenbag et al 1993; Dhingra et al 2000; Bhakuni et al 2002; Caniato \& Puricelli 2003). Besides its antimalarial activity, it also exhibits several biological activities, such as anti-inflammatory, anti-cancer, antioxidant, antifungal, antispasmodic, antimicrobial, insecticidal (Huang et al 1993; Zheng 1994; Liu et al 2001; Juteau et al 2002; Tripathi et al 2009).

In essential oil obtained from $A$. аппиа, camphor, artemisia ketone, germacrene $\mathrm{D}$ and 1,8-cineole are usually found as the main components (Ahmad \& Mishra 1994; Tellez et al 1999; Malik et al 2009; Brown 2010). This essential oil is used in the production of perfumes and cosmetics (Nedkov \& Attanassovo 2004).

It is generally accepted that variability of chemical composition of essential oil of $A$. annus depends on geographical origin and stage of plant development (C'avar et al 2012). The aim of the present study was to investigate the effect of different harvest stages on chemical composition and antioxidant capacity of essential oil from $A$. annua grown in Turkey.

\section{Material and Methods}

\subsection{Experimental design and agronomic practices}

This research was carried out at the experimental area of Mudurnu S.A. Vocational Higher School of Abant
İzzet Baysal University (Mudurnu, Bolu, Turkey) in 2011. The characteristics of experimental area were as follows: clay and loam, water saturated $51.7 \%$, total salt $0.09 \%, \mathrm{pH} 7.25$, lime $49.5 \%$, phosphorus $148.6 \mathrm{~kg} \mathrm{ha}^{-1}$, potassium $537.3 \mathrm{~kg} \mathrm{ha}^{-1}$ and, organic matter $1.36 \%$. Total rainfall, mean relative humidity and temperature in 2011 were recorded as 487.0 $\mathrm{mm}, 77.0 \%$, and $10.2{ }^{\circ} \mathrm{C}$, respectively. The seeds of $A$. апnиa were sown at a depth of $18 \mathrm{~cm}$ in plastic cases containing peat on April 2-3, 2011. On reaching an adequate height of average 10-15 $\mathrm{cm}$ average 2 months (on 27 June) after sowing in the greenhouse, seedlings were transplanted to the experimental area. When required, irrigation and weed control was made. Plants were harvested in four different stages as follows; before flowering (BF), in $50 \%$ of flowering $(50 \% \mathrm{~F})$, full flowering (FF) and, after flowering (AF). The BF, 50\% F, FF and, AF cuttings were made 98 days (on 4 October), 118 days (on 25 October), 123 days (on 1 November) and 129 days (on 8 November) after transplanting, respectively by hand.

\subsection{Essential oil analysis}

After each harvest, the aerial parts or herbage of the plants were dried in the shade at room temperature. Average $50 \mathrm{~g}$ of these parts ground was extracted using a Clevenger-type apparatus for $3 \mathrm{~h}$ in $500 \mathrm{ml}$ water. The resultant data (\%) were calculated as volume of essential oils per $50 \mathrm{~g}$ of plant dry matter.

\subsection{Gas chromatographic-mass spectrometric analysis of essential oil}

The chemical composition of the essential oils investigated was determined using a Hewlett Packard $6890 \mathrm{~N}$ GC, equipped with a HP 5MS $30 \mathrm{mx} 0.25$ $\mathrm{mmx} 0.25 \mu \mathrm{m}$ film thickness capillary column, a Hewlett Packard 5973 mass selective and FID detectors. The electron ionization energy of $70 \mathrm{eV}$ for GC/MS detection and $\mathrm{He}\left(1 \mathrm{~mL} \mathrm{~min}^{-1}\right)$ as the carrier gas was used. The temperatures of the injector and detector were set at $220^{\circ} \mathrm{C}$ and $290{ }^{\circ} \mathrm{C}$, respectively. The temperature of the column was initially set at 50 ${ }^{\circ} \mathrm{C}$ for $30 \mathrm{~min}$, and then increased gradually to 150 ${ }^{\circ} \mathrm{C}$ at a $3{ }^{\circ} \mathrm{C} \mathrm{min}-1$ rate, held for $10 \mathrm{~min}$, and finally reached to $250^{\circ} \mathrm{C}$. Diluted samples (1/100 in acetone, 
$\mathrm{V} \mathrm{V}^{-1}$ ) of $1.0 \mu \mathrm{L}$ were injected automatically at $250^{\circ} \mathrm{C}$, and in the splitless mode. The chemical composition of the essential oils was identified by matching their retention times and mass spectra with those obtained from the Flavor2.L, Wiley7n.1 and NIST98.L spectral and literature data. Relative percentages of the separated chemical components were calculated using FID chromatograms.

\subsection{Free radical-scavenging activity: DPPH assay}

The hydrogen atom or electron donation ability of the A. annus essential oils was measured from bleaching of purple-colored ethanol solution of DPPH (2.2-diphenyl-1-picrylhydrazyl). $20 \mu \mathrm{L}$ essential oil in methanol was added to $0.025 \mathrm{~g} \mathrm{~L}^{-1}$ methanol solution of DPPH and vortex-mixed. After $30 \mathrm{~min}$ of incubation, the absorbance was measured at 515 $\mathrm{nm}$, using a UV-Visible spectrophotometer (Burits \& Bucar 2000) and all tests were carried out in duplicate. Antiradical action toward DPPH radical was estimated from the difference in absorbance with or without sample (control). Inhibition of free radical DPPH in percent $(\mathrm{I} \%)$ was calculated in following way:
$I(\%)=\left(A_{\text {blank }}-A_{\text {sample }} / A_{\text {blank }}\right) \times 100$

Where; $\mathrm{A}_{\text {blank }}$ is the absorbance of the control reaction and $\mathrm{A}_{\text {sample }}$ is the absorbance of the absorbance of the test compound.

\subsection{Statistical analysis}

The results obtained from free radical-scavenging activity and essential oil was expressed as the means of 3 replications \pm standard error. All data were analyzed by analysis of variance (ANOVA) and the means were compared with Duncan's Multiple Range Tests. The statistical analysis was performed using TARIST package program (Açıkgöz et al 2004).

\section{Results and Discussion}

\subsection{Essential oil content and components}

The essential oil contents and components identified in herbage of the plants are listed in Table 1, together with their relative percentages, in order of their retention indices.

Table 1- Essential oil content and components of $A$. annua $\mathbf{L}$. at different harvest stages (\%)

Çizelge 1- Farklı hasat dönemlerinde A. annua L. 'nın uçucu yă̆ içeriği ve bileşenleri (\%)

\begin{tabular}{|c|c|c|c|c|c|}
\hline Compounds & $R T$ & $B F$ & $50 \% F$ & $F F$ & $A F$ \\
\hline$\alpha$-pinene & 9.65 & 5.56 & 7.11 & 1.59 & 5.12 \\
\hline camphene & 10.27 & 4.97 & 3.13 & 3.41 & 2.79 \\
\hline sabinene & 11.34 & 1.25 & 1.36 & 1.23 & 1.10 \\
\hline$\beta$-pinene & 11.46 & 1.01 & 0.94 & 0.54 & 0.72 \\
\hline myrcene & 12.15 & 1.10 & 1.11 & 0.72 & 0.68 \\
\hline 1,8-cineole & 14.22 & 9.85 & 9.44 & 10.39 & 9.00 \\
\hline$\gamma$-terpinene & 15.49 & - & 0.25 & - & 0.21 \\
\hline artemisia ketone & 15.51 & 34.93 & 28.30 & 37.15 & 36.93 \\
\hline artemisia alcohol & 16.47 & 3.65 & 4.09 & 3.94 & 3.91 \\
\hline camphor & 19.26 & 22.69 & 18.75 & 23.80 & 18.00 \\
\hline pinocarvone & 20.08 & 1.29 & 3.96 & 0.76 & 4.23 \\
\hline isoborneol & 20.52 & - & 0.16 & - & 0.12 \\
\hline 4-carvomenthenol & 20.78 & 0.54 & 0.62 & 0.49 & 0.52 \\
\hline$\alpha$-terpineol & 21.42 & 0.32 & 0.40 & 0.25 & 0.25 \\
\hline myrtenol & 21.66 & 0.47 & 0.48 & 0.32 & 0.45 \\
\hline copaene & 29.98 & 0.68 & 0.48 & 0.77 & 0.92 \\
\hline$\beta$-caryophyllene & 31.82 & 1.73 & 2.42 & 1.90 & 2.11 \\
\hline$\beta$-cubebene & 34.06 & 1.71 & 3.05 & 2.29 & 2.44 \\
\hline$\beta$-selinene & 34.28 & 4.61 & 4.44 & 3.34 & 2.96 \\
\hline caryophyllene oxide & 38.09 & 0.72 & 0.80 & 0.50 & 0.71 \\
\hline Total & & 97.08 & 91.29 & 93.39 & 93.17 \\
\hline Essential oil content $(\%)$ & & $0.8^{\mathrm{c}}$ & $0.96^{\mathrm{bc}}$ & $1.22^{\mathrm{ab}}$ & $1.38^{\mathrm{a}}$ \\
\hline
\end{tabular}

${ }^{\mathrm{a}}$, the same letter are not significantly different at $\mathrm{P}>0.05$ 
Essential oil content was recorded as $0.80 \%$ in $\mathrm{BF}$ stage. 18 components composing 97.08\% of the oil were determined. Artemisia ketone (34.93\%), camphor (22.69\%) and 1,8-cineole $(9.85 \%)$ were recorded as the main components. $\alpha$-pinene, camphene, $\beta$-selinene, artemisia alcohol, $\beta$-caryophyllene, $\beta$-cubebene, pinocarvone, sabinene, myrcene and $\beta$-pinene were found 5.56, 4.97, $4.61,3.65,1.73,1.71,1.29,1.25,1.10$ and $1.01 \%$, respectively. Contents of five compounds constituting $2.73 \%$ of the essential oil in total were found below $1 \%$ each. In the $50 \% \mathrm{~F}$ stage, the content of essential oil was obtained $0.96 \%$ and 20 compounds representing $91.29 \%$ of the oil were identified, with major compounds being: Artemisia ketone $(28.30 \%)$, camphor $(18.75 \%)$ and 1,8-cineole $(9.44 \%)$. In addition, the ratio of $\alpha$-pinene, $\beta$-selinene, artemisia alcohol, pinocarvone, camphene and $\beta$-cubebene were recorded 7.11, 4.44, 4.09, 3.96, 3.13 and 3.05, respectively. The other compounds accounted for $2.42 \%$ to $0.16 \%$ of the total essential oil.

The total essential oil content from $\mathrm{FF}$ and $\mathrm{AF}$ stages were obtained $1.22 \%$ and 1.38 , respectively. In FF stage, 18 components of which the first three components (artemisia ketone, camphor and 1,8 -cineole) representing $71.34 \%$ of the oil (37.15\%, 23.80\% and $10.39 \%$, respectively) were identified. The percentage amounts of artemisia alcohol, camphene, $\beta$-selinene, $\beta$-cubebene, $\beta$-caryophyllene, $\alpha$-pinene and sabinene were recorded 3.94, 3.41, 3.34, 2.29, 1.90, 1.59 and 1.23\%, respectively. On the other hand, the percentage amounts of the other 8 compounds accounting for $4.35 \%$ of the total essential oil did not exceed $1 \%$. The 20 compounds comprising $93.17 \%$ of the essential oil were characterized in the FF stage. Artemisia ketone (36.93\%), camphor (18.00\%) and 1,8-cineole $(9.00 \%)$ were predominant components in this oil. The percentage amounts of $\alpha$-pinene, pinocarvone, artemisia alcohol, $\beta$-selinene, camphene, $\beta$-cubebene, $\beta$-caryophyllene and sabinene were recorded 5.12, 4.23, 3.91, 2.96, 2.79, $2.44,2.11$ and $1.10 \%$, respectively. Also, the other components identified were found below $1 \%$.

The differences among essential oils investigated were significant statistically $(\mathrm{P}<0.05)$. The highest
$(1.38 \%)$ and the lowest $(0.8 \%)$ essential oil ratio were obtained from AF and BF stages, respectively (Figure 1). Also, the essential oil ratio increased with the delay in harvest stages. Similarly, in the study carried out in India, the essential oil content in the aerial parts of $A$. апnиa was found to vary from $0.3 \%$ to $0.7 \%$ at different stages of growth. Also, the plants harvested at full flowering and seed setting stage gave higher yield of essential oil $(0.6 \%, 0.7 \%)$ than that harvested at pre-flowering $(0.5 \%)$, late vegetative $(0.4 \%, 0.5 \%)$, mid vegetative $(0.4 \%$, $0.4 \%)$ and early vegetative stages $(0.3 \%, 0.3 \%)$ (Padalia et al 2011).

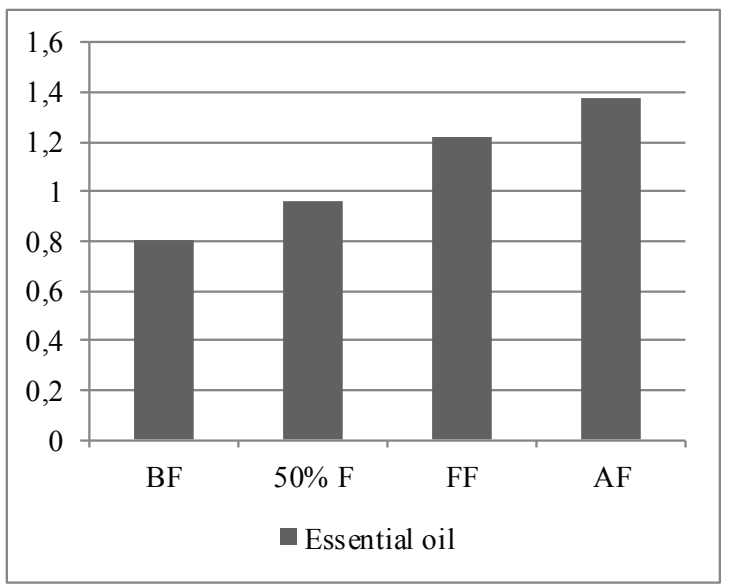

Figure 1- Essential oil contents in A. annua L. according to harvest periods (\%)

Şekil 1- Hasat dönemlerine göre A.аnnua'da uçucu yağ içerikleri (\%)

In our study, the variations in the amounts of artemisia ketone, camphor and 1,8-cineole of the essential oils investigated were significant statistically $\quad(\mathrm{P}<0.05, \quad \mathrm{P}<0.01$ and $\mathrm{P}<0.01$, respectively) during the time of harvest (Figure 2). Several components in A. апnиа essential oil have been identified. Significant variations in the percentage of different components in essential oils from A. аппиа have been recorded. Generally, artemisia ketone, artemisia alcohol, camphor, 1.8-cineole and germacrene $\mathrm{D}$ were the main components. But, the chemical composition of the essential oil varied depending on several factors 
such as geographical origin, stages of development, climatic factors, etc. The main components of the essential oil from A. annua growing wild in Bulgaria were $\alpha$-caryophillene $(24.73 \%), \quad \alpha$-cuvebene (13.53\%), $\alpha$-copaene (7.24\%), $\alpha$-selinene $(8.21 \%)$, artemisia ketone $(8.45 \%)$, and camphor $(3.61 \%)$ (Tzenkova et al 2010). In the essential oil of $A$. annua plants cultivated in India, camphor (10.5$44.4 \%$ ) was found to be the major constituent of oil instead of the usually dominant artemisia ketone (Bagchi et al 2003). According to Jain et al (2002), artemisia ketone (52.9\%), 1.8-cineole (8.4\%) and camphor $(6.0 \%)$ were the major components. Soylu et al (2005) stated that chemical analysis revealed that the $A$. апnиa essential oil was rich in camphor (31.7\%), 1.8-cineole (10.1\%), caryophyllene oxide (7.1\%), $\alpha$-copaene $(3.4 \%)$ and camphene $(3.3 \%)$.

The content of chemical compounds in the essential oil of $A$. апnиa depends on time of harvesting of the plant material (C'avar et al 2012). Chemical compositions of essential oils from A.annua plants harvested in different flowering stage have been varied. Yu et al (2011) reported that $\beta$-myrcene $(37.71 \%), 1.8$-cineole $(16.11 \%)$, germacrene D (18.1\%), camphor (15.84\%) and (Z)- $\beta$-farnesene $(9.43 \%)$ were main compounds in the pre-flowering oil; camphor (16.62\%), caryophyllene $(16.27 \%), \quad \beta$-caryophyllene oxide $(15.84 \%), \beta$-farnesene $(9.05 \%)$ and (-)-spathulenol $(7.21 \%)$ were major compounds in the postflowering oil. Correspondingly, the highest amounts of the main compounds (artemisia ketone, camphor and 1.8-cineole) in the essential oils investigated were recorded in the essential oils of the plants from the FF stage in our study (Figure 2).

The chemical composition and amount of essential oils are influenced by the time of harvest, and may vary according to the developmental stages of the plants. The biosynthesis of essential oil components is low in the vegetative stage of plants. The enzymes necessary to the biosynthesis of some components are not active during the vegetative stage. Thus, the harvest stage is one of the most important factors affecting essential oil quality (Nurzyńsja-Wierdak 2013; Rodrigues et al 2013).

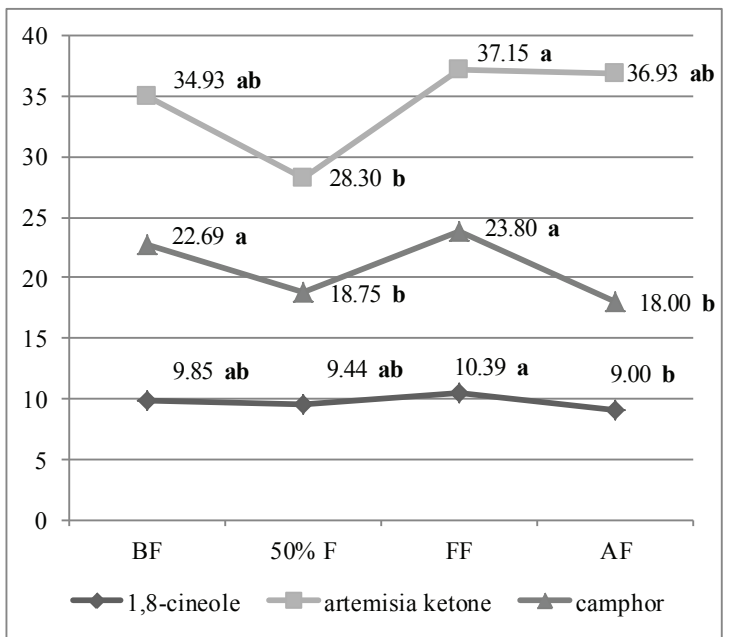

Figure 2- Variation in the major components of $A$. annua $\mathrm{L}$. essential oils according to four harvest periods (\%) (aynı harfler arasındaki fark $\mathbf{P}<\mathbf{0 . 0 5}$ düzeyinde önemli değildir.)

Şekil 2- A. annua uçucu yağının ana bileşenlerinin dört hasat dönemine göre değişimi (\%) (the same letter are not significantly different at $P<0.05$ )

\subsection{Free radical-scavenging activity: DPPH assay}

The free radicals i.e. $\alpha, \alpha$-diphenyl- $\beta$-picrylhydrazyl scavenging activity of the essential oils from $A$. annua was tested by using DPPH method and the results were evaluated in Table 2.

Table 2- Free radical scavenging activity of $A$. annua L. essential oils by DPPH methods

Çizelge 2- DPPH metoduyla A. апnиa L. ис̧иси yağlarının serbest radikal yakalama aktivitesi

\begin{tabular}{cc}
\hline Stages & $D P P H($ Inhibition, \%) \\
\hline BF & $78.29 \pm 2.740^{\mathrm{b}}$ \\
$50 \% \mathrm{~F}$ & $86.76 \pm 0.865^{\mathrm{a}}$ \\
$\mathrm{FF}$ & $86.99 \pm 0.625^{\mathrm{a}}$ \\
$\mathrm{AF}$ & $83.62 \pm 0.390^{\mathrm{a}}$ \\
\hline
\end{tabular}

${ }^{a}$, the values are means \pm standard error; means with the same letter are not significantly different at $\mathrm{P}>0.05$

The antioxidant principle in their interaction depends on oxidative free radicals. The main mechanism of DPPH method is that the bioactive compounds react with a stable free radical i.e. $\alpha$, 
$\alpha$-diphenyl- $\beta$-picrylhydrazyl. It is converted to $\alpha$, $\alpha$-diphenyl- $\beta$-picrylhydrazine with discoloration. The gradually color change indicates the scavenging activities of the samples investigated due to bioactive compounds such as phenolic compounds, flavonoids, terpenoids and derivatives (Al Nomaani et al 2013). In the present study, four essential oils obtained from $A$. апnиa were able to decolorize DPPH. The free radical scavenging activities of essential oils were found to be in the order of $\mathrm{FF}>50 \% \mathrm{~F}>\mathrm{AF}>\mathrm{BF}$. Statistically significant effect $(\mathrm{P}<0.05)$ of harvest stage on the free radical scavenging activities of essential oils was observed (Table 2).

In general, the antioxidative effectiveness of essential oil depends on the content of phenolic compounds (C'avar et al 2012; Haşimi et al 2014). It is known that essential oils obtained from plants belonging to the Artemisia genus are markedly rich in non-phenolic constituents (Lopes-Lutz et al 2008). The essential oils having non-phenolic compounds showed the weak antioxidant activity (Juteau et al 2002; Mighri et al 2010). The essential oil of A. annua aerial parts, consisting of camphor (44\%), germacrene D (16\%), trans-pinocarveol (11\%), $\beta$-selinene $(9 \%)$, $\beta$-caryophyllene ( $9 \%$ ) and artemisia ketone (3\%), was observed the weak antioxidant activity (Juteau et al 2002). Similar results were found with essential oils of several Artemisia species such as A. absinthum, A. biennis, A. cana, A. dracunculus, $A$ frigida, $A$. longifolia, A. herba-alba and A. ludoviciana, which are dominant by non-phenolic components (LopesLutz et al 2008; Mighri et al 2010). The essential oil of A. annua has antioxidant activity and metal chelating activity similar to thymol, a known antioxidant (C'avar et al 2012).

\section{Conclusions}

Our results indicated that the different harvest stages have significant effect on percentage, chemical composition and antioxidant capacity of essential oil from A. annua. The essential oil was low in BF stage $(0.8 \%)$, but rapidly increasing in the other harvest stages $(0.96,1.22$, and $1.38 \%$ for $50 \% \mathrm{~F}$, $\mathrm{FF}$, and AF stages, respectively). Main compounds (artemisia ketone, camphor and 1.8-cineole) amounts were the highest in FF stage. All essential oils showed potent free radical-scavenging activity. But, the highest activity was recorded in essential oil of plant harvested in FF stage.

\section{Acknowledgements}

This study was supported by Abant Izzet Baysal University (Project No: BAP-2012.24.24.481).

\section{References}

Açıkgöz N, İlker E \& Gokcol A (2004). Biyolojik araştırmaların bilgisayarda değerlendirmeleri. Ege University Publication No: 2, Izmir

Ahmad A \& Mishra L N (1994). Terpenoids from Artemisia annua and constituents of its essential oil. Phytochemistry 37(1): 183-186

Al Nomaani C R S, Hossain M A, Weli A M, Al- Riyami Q, Al-Sabahi J N \& Rahman S M (2013). Chemical composition of essential oils and in vitro antioxidant activity of fresh and dry leaves crude extracts of medicinal plant of Lactuca sativa L. native to Sultanate of Oman. Asian Pacific Journal of Tropical Medicine 3(5): 353-357

Bagchi G D, Haider F, Dwivedi P D, Singh A \& Naqvi A A (2003). Essential oil constituents of Artemisia annua during different growth periods at monsoon conditions of subtropical North Indian plains. Journal of Essential Oil Research 15(4): 248-250

Baser K H C \& Buchbauer G (2010). Handbook of essential oils science, technology, and applications. In: $G$ Buchbauer (Ed), Biological Activities of Essential Oils, New York, pp. 235-273

Bhakuni R S, Jain D C, Sharma R P \& Kumar S (2001). Secondary metabolites of Artemisia annua and their biological activity. Current Science 80(1): 35-48

Brown G D (2010). The biosynthesis of artemisinin (Qinghaosu) and the phytochemistry of Artemisia annua L. (Qinghao). Molecules 15(11): 7603-7698

Burits M \& Bucar F (2000). Antioxidant activity of Nigella sativa essential oil. Phytotheraphy Research 14(5): 323-328

C'avar S, Maksimovi'c M, Vidic D \& Pari'c A (2012). Chemical composition and antioxidant and antimicrobial activity of essential oil of Artemisia annua L. from Bosnia. Industrial Crops and Products 37: 479-485

Caniato R \& Puricelli L (2003). Natural antimalarial agents (1995-2001). Critical Reviews in Plant Sciences 22(1): 79-105 
Dhingra V, Pakki S R \& Narasu M L (2000). Antimicrobial activity of artemisinin and its precursors. Current Science 78(6): 709-713

Ferreira J F S, Zheljazkov V D \& Gonzaleza J M (2013). Artemisinin concentration and antioxidant capacity of Artemisia annua distillation byproduct. Industrial Crops and Products 41: 294-298

Haşimi N, Tolan V, Kızıl S \& Kılınç E (2014). Determination of essential oil composition, antimicrobial and antioxidant properties anise (Pimpinella anisum L.) and cumin (Cuminum cyminum L.) seeds. Tarim Bilimleri Dergisi-Journal of Agricultural Sciences 20 (1): 19-26

Huang L, Liu J F, Liu L X, Li D F, Zhang Y, Nui H Z, Song H Y \& Zhang C Y (1993). Antipyretic and antiinflammatory effects of Artemisia annua L. Zhongguo Zhong Yao Za Zhi 18(1): 44-48

Jain N, Srivastava S K, Aggarwal K K, Kumar S \& Syamasundar K V (2002). Essential oil composition of Artemisia annua L. 'Asha' from the plains of northern India. Journal of Essential Oil Research 14(4): 305-307

Juteau F, Masotti V, Bessiere J M, Dherbomez M \& Viano J (2002). Antibacterial and antioxidant activities of Artemisia annua essential oil. Fitoterapia 73(6): 532-535

Liu C H, Zou W X, Lu H \& Tan R X (2001). Antifungal activity of Artemisia annua endophyte cultures against phytopathogenic fungi. Journal of Biotechnology $\mathbf{8 8}$ (3): $277-282$

Lopes-Lutz D, Alviano D S, Alviano C S \& Kolodziejczyk P P (2008). Screening of chemical composition, antimicrobial and antioxidant activities of Artemisia essential oils. Phytochemistry 69(8): 1732-1738

Malik AA, Showkat J A, Mir R, Ali A \& Abdin M Z (2009). Influence of chemical and biological treatments on volatile oil composition of Artemisia annua Linn. Industrial Crops and Products 30(3): 380-383

Mighri H, Hajlaoui H, Akrouta A, Najjaa H \& Neffat M (2010). Antimicrobial and antioxidant activities of Artemisia herba-alba essential oil cultivated in Tunisian arid zone. Comptes Rendus Chimie 13(3): 380-386

Nedkov N \& Attanassova M (2004). Essential Oil and Medicinal Crops. Kameja Press, Sofia, Bulgaria

Nibret E \& Wink M (2010). Volatile components of four Ethiopian Artemisia species extracts and their in vitro antitrypanosomal and cytotoxic activities. Phytomedicine 17(5): 369-374

Nurzyńska-Wierdak R (2013). Essential oil composition of the coriander (Coriandrum sativum L.) herb depending on the development stage. Acta Agrobotanica 66(1): 53-60
Padalia R C, Verma R S, Chauhan A, Chanotiya C S \& Yadav A (2011). Variation in the volatile constituents of Artemisia annua var. CIM-Arogya during plant ontogeny. Natural Product Communications 6(2): 239-242

Pellicer J, Garcia S, Garnatje T, Oriane H, Korobkov A A, Dariimaa S \& Vallès J (2007). Chromosome counts in Asian Artemisia L. (Asteraceae) species: from diploids to the first report of the highest polyploidy in the genus. Botanical Journal of the Linnean Society 153(3): 301-310

Rodrigues, L, Póvoa O, Teixeira G, Figueiredo A C, Moldão M, Monteiro A (2013). Trichomes micromorphology and essential oil variation at different developmental stages of cultivated and wild growing Mentha pulegium L. populations from Portugal. Industrial Crops and Products 43: 692-700

Soylu E M, Yiğitbaş H, Tok F M, Soylu S, Kurt S, Baysal O \& Kaya A D (2005). Chemical composition and antifungal activity of the essential oil of Artemisia annua L. against foliar and soil-borne fungal pathogens. Zeitschrift für Pflanzenkrankheiten und Pflanzenschutz Journal of Plant Diseases and Protection 112(3): 229-239

Tellez M R, Canel C, Rimando A M \& Duke SO (1999). Differential accumulation of isoprenoids in glanded and glandless Artemisia annua L. Phytochemistry 52(6): 1035-1040

Tripathi, A K, Prajapati V, Aggarwal K K, Khanuja S P S \& Kumar S (2009). Repellency and toxicity of oil from Artemisia annua to certain stored-product beetles. Journal of Economic Entomology 93: 43-47

TUBIVES (2013). Turkish Plant Data Service. Available: http://turkherb.ibu.edu.tr (Erişim tarihi:18.12.2013)

Tzenkova R, Kamenarska Z, Draganov A \& Atanassov A (2010). Composition of Artemisia annua essential oil obtained from species growing wild in Bulgaria. Biotechnology \& Biotechnological Equipment 24(2): 1833-1835

Woerdenbag H J, Bos R, Salomons M C, Hendriks H, Pras N \& Malingre T M (1993): Volatile constituents of Artemisia annua L. (Asteraceae). Flavour and Fragrance Journals 8: 131-137

Yu Z W, Wang B C, Yang F M, Sun Q Y, Yang Z N \& Zhu L C (2011). Chemical composition and antiacetylcholinesterase activity of flower essential oils of Artemisia annua at different flowering stage. Iranian Journal of Pharmaceutical Research 10(2): 265-271

Zheng G Q (1994). Cytotoxic terpenoids and flavonoids from Artemisia annua. Planta Medica 60(1): 54-57 